\title{
Effect of vagotomy on the gastric secretory response to intraduodenal osmotic agents in man
}

\author{
A. S. WARD \\ From the University Department of Surgery, Sheffield Royal Infirmary, Sheffield
}

SUMMARY The effect of intraduodenal infusion of hypertonic saline and glucose on pentagastrinstimulated gastric secretion was investigated in 35 normal subjects, 32 duodenal ulcer patients, and 32 patients after truncal vagotomy and pyloroplasty. A significant gastric inhibitory response occurred after $0.51 \mathrm{M}$ saline and $1.03 \mathrm{M}$ glucose in the normal subjects and duodenal ulcer patients but after vagotomy there was no inhibition. This finding suggests that the inhibitory effect of these agents depends, at least in part, on a vagal reflex in man. The response to very high glucose concentrations persisted after vagotomy and it seems likely that a humoral mechanism may be involved in this situation.

Intraduodenal infusion of hypertonic saline and glucose is known to inhibit gastric secretion both in animals (Matsuyama, 1932; Sircus, 1958) and in man (Shay et al., 1942b; Ward et al., 1969). The response has not been studied in detail, however, and little is known of the mechanisms mediating this inhibitory effect. The role of the vagus in particular requires definition and the present paper reports an investigation into this problem in man.

\section{Methods}

Thirty-five normal subjects ( 32 male; three female), 32 patients with chronic duodenal ulceration (30 male; two female), and 32 vagotomized subjects ( 29 male; three female) were studied. The mean ages were 42 years (22-59 years), 47 years (26-61 years), and 49 years (37-68 years). The normal subjects were volunteers awaiting minor inpatient surgery and all were free from gastrointestinal symptoms. The duodenal ulcer patients were awaiting gastric surgery and in all cases the nature of the pathology was confirmed at subsequent laparotomy. The vagotomized patients were tested six months or more after truncal vagotomy and pyloroplasty. Completeness of gastric vagal section was confirmed by a Hollander test before proceeding with the duodenal inhibitory test. The response to insulin was assessed on the basis of Hollander's original criteria (1948) as well as the additional criteria of subsequent

Received for publication 14 October 1975 authors (Waddell, 1957; Bachrach, 1962; Ross and Kay, 1964; Bank et al., 1967).

The agents infused into the duodenum were 1.03 M glucose (c. $1000 \mathrm{mosm} / \mathrm{l}$ ), $2.75 \mathrm{M}$ glucose (c. 2800 $\operatorname{mosm} / \mathrm{l}$ ), and $0.51 \mathrm{M}$ sodium chloride (c. 1000 mosm/l). The choice of these solutions was somewhat arbitrary, though each was thought to represent an adequate osmotic stimulus. Two concentrations of glucose were employed in order to assess the role of the vagus at different levels of osmolarity.

Gastric inhibition was investigated using methods previously described (Ward, 1973). A fine polyvinyl tube was placed in the distal duodenum and a large bore sump tube positioned in the gastric antrum. Gastric secretion was stimulated by a continuous intravenous infusion of pentagastrin $(6 \mu \mathrm{g} / \mathrm{kg} / \mathrm{h}$ in normal subjects and preoperative patients, $9 \mu \mathrm{g} / \mathrm{kg} / \mathrm{h}$ in vagotomized subjects), and 10 minute gastric collections were made throughout each test. Once a secretory plateau had been reached, which was usually by an hour, $40 \mathrm{ml}$ of the test reagent, at $37^{\circ} \mathrm{C}$, were infused into the distal duodenum over a five minute period. Gastric collection was then continued for a further hour.

\section{DUODENOGASTRIC REFLUX}

Reflux of duodenal contents into the stomach is a potential problem in this type of study, particularly after pyloroplasty. Attempts were made to minimize this reflux by using a fine duodenal tube and a slow rate of perfusion. In addition, reagents were instilled into the distal rather than the proximal duodenum. 
Reflux was monitored in each test by 'labelling' the infusate with $0.2 \mathrm{~g} / 1$ polyethylene glycol 4000 . The total amount of polyethylene glycol infused on each occasion was thus $800 \mathrm{mg}$, and recovery of more than $50 \mathrm{mg}$ in post-instillation gastric samples was deemed unsatisfactory and the test discarded. Reflux was invariably accompanied by an increase in volume of the gastric aspirate and a decrease in acid concentration and observation of these parameters served as an additional method of monitoring reflux.

\section{ASSESSMENT OF INHIBITION}

Gastric inhibition was assessed in each test by comparing the acid output before and after duodenal infusion. The pre-infusion acid output was represented by the mean of the three 10 minute plateau collections. Acid output during inhibition was represented by the mean of the three lowest consecutive collections immediately after duodenal infusion. In those tests in which inhibition was of 20 minutes' duration only, the inhibitory output was represented by the mean of the two lowest consecutive collections after duodenal infusion.

\section{STATISTICAL ANALYSIS}

Acid output before and after duodenal infusion was compared in each group of normal subjects, duodenal ulcer patients and vagotomized subjects using a paired $t$ test. An unpaired $t$ test was used to compare the response in dissimilar groups. The population size in each group is small and a nonparametric test (Wilcoxon's signed rank test) was also performed to confirm the significance of the difference between pre- and post-infusion values independently of the normality of the distribution.

\section{Results}

\section{CONTROL STUDIES}

1. A pentagastrin infusion was administered on its own for three hours in four normal subjects, four duodenal ulcer patients, and four vagotomized patients (dose rate $6 \mu \mathrm{g} / \mathrm{kg} / \mathrm{h}$ in the normal subjects and preoperative patients; $9 \mu \mathrm{g} / \mathrm{kg} / \mathrm{h}$ in the postoperative group). The purpose of this infusion was to detect any spontaneous diminution in the gastric secretory response with time. None was noted.

2. In four normal subjects, four duodenal ulcer patients, and four patients after truncal vagotomy and pyloroplasty $40 \mathrm{ml} 0.15 \mathrm{M}$ sodium chloride were infused into the duodenum over a five minute period during pentagastrin stimulation. There was no effect on the plateau output in any instance and changes occurring after intraduodenal hypertonic saline and glucose may be attributed to effects other than those induced by a simple volume instillation.
RESPONSE TO HYPERTONIC GLUCOSE

\section{$1.03 \mathrm{M}$ glucose}

The effect of intraduodenal $1.03 \mathrm{M}$ glucose on gastric acid output was investigated in 13 normal subjects, 12 duodenal ulcer patients, and 10 patients after truncal vagotomy and pyloroplasty (Table 1).

Inhibition of acid output occurred in 11 normal subjects and all 12 duodenal ulcer patients. The mean response was highly significant in both groups ( $\mathrm{P}<$ 0.001 ). Inhibition was evident immediately after the start of the duodenal infusion and lasted for approximately 30 minutes in most cases. An example is shown in Fig. 1a. The response was characterized by a reduction in gastric secretory volume, acid concentration remaining unchanged.

\begin{tabular}{|c|c|c|c|c|}
\hline & \multicolumn{2}{|c|}{ Acid output (mmol/10 $\mathrm{min})$} & \multirow{2}{*}{$\begin{array}{l}\text { Inhibition } \\
\text { (mmol/10 min) }\end{array}$} & \multirow[t]{2}{*}{$\boldsymbol{P}$} \\
\hline & $\begin{array}{l}\text { During } \\
\text { plateau }\end{array}$ & $\begin{array}{l}\text { After duodenal } \\
\text { infusion }\end{array}$ & & \\
\hline \multicolumn{5}{|c|}{ Normal subjects (13) } \\
\hline $\begin{array}{l}\text { Mean } \\
\text { SE }\end{array}$ & $\begin{array}{l}4 \cdot 30 \\
0 \cdot 30\end{array}$ & $\begin{array}{l}2.27 \\
0.42\end{array}$ & $\begin{array}{l}2 \cdot 03 \\
0 \cdot 38\end{array}$ & $<0.001$ \\
\hline \multicolumn{5}{|c|}{ Duodenal ulcer patients (12) } \\
\hline $\begin{array}{l}\text { Mean } \\
\text { SE }\end{array}$ & $\begin{array}{l}7 \cdot 63 \\
0.57\end{array}$ & $\begin{array}{l}5.05 \\
0.53\end{array}$ & $\begin{array}{l}2.58 \\
0.43\end{array}$ & $<0.001$ \\
\hline \multicolumn{5}{|c|}{$T V+P(10)$} \\
\hline $\begin{array}{l}\text { Mean } \\
\text { SE }\end{array}$ & $\begin{array}{l}2.67 \\
0.35\end{array}$ & $\begin{array}{l}2 \cdot 69 \\
0.34\end{array}$ & $\begin{array}{r}0.02 \\
0.03\end{array}$ & NS \\
\hline
\end{tabular}

Table 1 Effect of intraduodenal $1 \cdot 03 \mathrm{M}$ glucose on gastric acid output in man

There was no change in acid output in any of the patients tested after truncal vagotomy and pyloroplasty. In two instances it was possible to examine the response to $1.03 \mathrm{M}$ glucose both before and after vagotomy and one of these tests is illustrated in Fig. 1a, b. Gastric inhibition was evident before operation in this patient, but after vagotomy there was no response.

\section{$2.75 \mathrm{M}$ glucose}

The effect of intraduodenal $2.75 \mathrm{M}$ glucose on gastric secretion was investigated in five normal subjects, four duodenal ulcer patients, and six patients after truncal vagotomy and pyloroplasty (Table 2).

Inhibition occurred in all the normal subjects and duodenal ulcer patients. The mean inhibitory response in both groups was highly significant $(P<$ 0.001 ). As in the case of $1.03 \mathrm{M}$ glucose inhibition was achieved almost entirely by a volume reduction. After vagotomy, an inhibitory response was obtained in four of the six patients. Mean inhibition (all six patients) was significant at the $P<0.05$ level. One 


\begin{tabular}{|c|c|c|c|c|}
\hline & \multicolumn{2}{|c|}{ Acid output (mmol/10 min) } & \multirow{2}{*}{$\begin{array}{l}\text { Inhibition } \\
(\text { mmol/10 min })\end{array}$} & \multirow[t]{2}{*}{$P$} \\
\hline & $\begin{array}{c}\text { During } \\
\text { plateau }\end{array}$ & $\begin{array}{l}\text { After duodenal } \\
\text { infusion }\end{array}$ & & \\
\hline \multicolumn{5}{|c|}{ Normal subjects (5) } \\
\hline $\begin{array}{l}\text { Mean } \\
\text { SE }\end{array}$ & $\begin{array}{l}4 \cdot 88 \\
0 \cdot 38\end{array}$ & $\begin{array}{l}2.92 \\
0 \cdot 10\end{array}$ & $\begin{array}{l}1.96 \\
0.31\end{array}$ & $<0.01$ \\
\hline \multicolumn{5}{|c|}{ Duodenal ulcer patients (4) } \\
\hline $\begin{array}{l}\text { Mean } \\
\text { SE }\end{array}$ & $\begin{array}{l}7.44 \\
0.75\end{array}$ & $\begin{array}{l}2.56 \\
0.65\end{array}$ & $\begin{array}{l}4 \cdot 88 \\
0.80\end{array}$ & $<0.001$ \\
\hline \multicolumn{5}{|c|}{$T V+P(6)$} \\
\hline $\begin{array}{l}\text { Mean } \\
\text { SE }\end{array}$ & $\begin{array}{l}2.69 \\
0.40\end{array}$ & $\begin{array}{l}1.64 \\
0.37\end{array}$ & $\begin{array}{l}1.05 \\
0.32\end{array}$ & $<0.05$ \\
\hline
\end{tabular}

Table 2 Effect of intraduodenal 2.75 M glucose on gastric acid output in man

patient was tested with $2.75 \mathrm{M}$ glucose both before and after vagotomy (Fig. 2a, b). Marked gastric inhibition occurred in the preoperative test; after vagotomy an inhibitory effect was still apparent despite the absence of a vagal nerve supply. One vagotomized patient received $1.03 \mathrm{M}$ and $2.75 \mathrm{M}$ glucose in sequence (Fig. 3). The former solution was without effect, while a gastric inhibitory response was clearly evident after $2.75 \mathrm{M}$ glucose infusion.

RESPONSE TO HYPERTONIC SALINE

The gastric response to intraduodenal $0.51 \mathrm{M}$ saline was investigated in 12 normal subjects, 12 duodenal ulcer patients, and 10 patients after truncal vagotomy and pyloroplasty (Table 3 ).

Inhibition occurred in seven of the normal subjects and in nine duodenal ulcer patients. The mean response was significant in both groups $(P<0.01$ and $P<0.001$ respectively). Inhibition was immediate

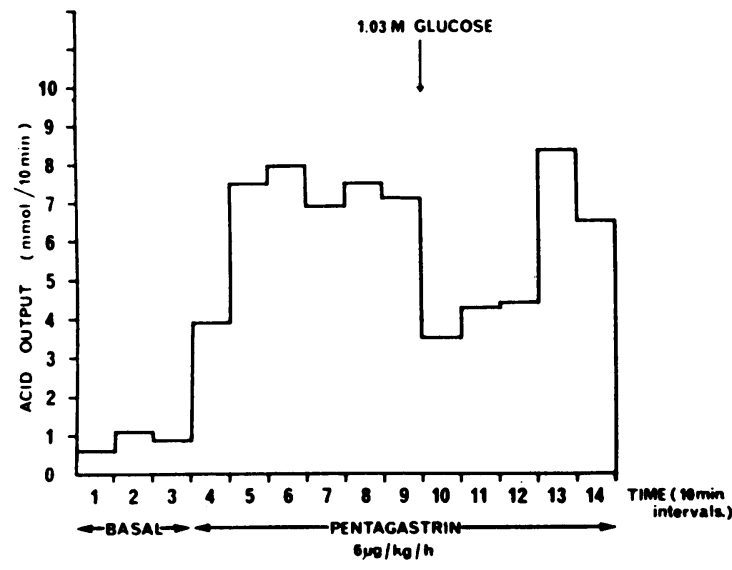

(a)

\begin{tabular}{|c|c|c|c|c|}
\hline & \multicolumn{2}{|c|}{ Acid output (mmol/10 min) } & \multirow{2}{*}{$\begin{array}{l}\text { Inhibition } \\
(\mathrm{mmol} / 10 \mathrm{~min})\end{array}$} & \multirow[t]{2}{*}{$\boldsymbol{P}$} \\
\hline & $\begin{array}{l}\text { During } \\
\text { plateau }\end{array}$ & $\begin{array}{l}\text { After duodenal } \\
\text { infusion }\end{array}$ & & \\
\hline \multicolumn{5}{|c|}{ Normal subjects (12) } \\
\hline $\begin{array}{l}\text { Mean } \\
\text { SE }\end{array}$ & $\begin{array}{l}5.19 \\
0.58\end{array}$ & $\begin{array}{l}4.36 \\
0.67\end{array}$ & $\begin{array}{l}0.83 \\
0.21\end{array}$ & $<0.01$ \\
\hline \multicolumn{5}{|c|}{ Duodenal ulcer patients (12) } \\
\hline $\begin{array}{l}\text { Mean } \\
\text { SE }\end{array}$ & $\begin{array}{l}7.88 \\
0.91\end{array}$ & $\begin{array}{l}5.95 \\
1.03\end{array}$ & $\begin{array}{l}1.93 \\
0.39\end{array}$ & $<0.001$ \\
\hline \multicolumn{5}{|c|}{ TV $+P(10)$} \\
\hline $\begin{array}{l}\text { Mean } \\
\text { SE }\end{array}$ & $\begin{array}{l}2.65 \\
0.36\end{array}$ & $\begin{array}{l}2.77 \\
0.32\end{array}$ & $\begin{array}{r}+0.12 \\
0.08\end{array}$ & NS \\
\hline
\end{tabular}

Table 3 Effect of intraduodenal 0.51 M saline on gastric acid output in man

in onset and of 20 to 30 minutes' duration (Fig. 4a). The response was achieved by a volume reduction in approximately half of the cases, while a decrease in acid concentration occurred in the remainder.

Acid output was unchanged in eight of the 10 patients tested after truncal vagotomy and pyloroplasty. In the remaining two patients there was a small increase in gastric secretion in the second half of the test. Two patients were successfully tested both before and after vagotomy and the response in one of these patients is shown in Fig. 4a, b. Inhibition was clearly evident before operation in this patient but after vagotomy there was no response.

\section{Discussion}

The results of this study show that intraduodenal infusion of hypertonic glucose and saline may signifiantly inhibit pentagastrin-stimulated gastric secre-

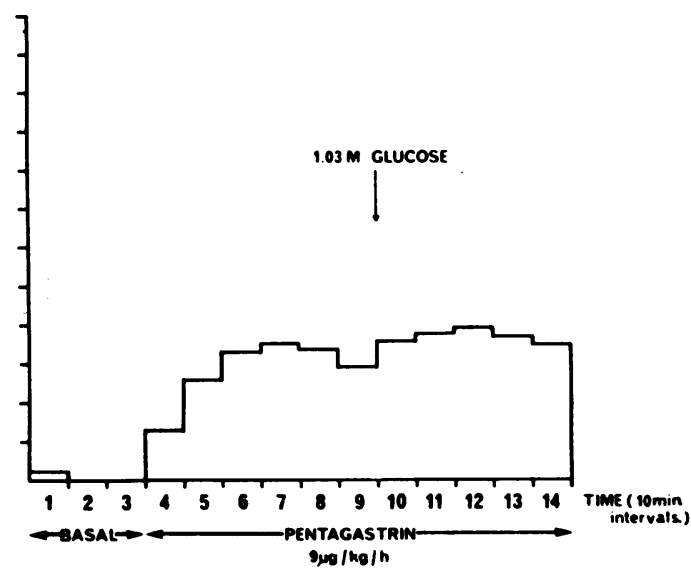

(b)

Fig. 1 The effect of intraduodenal $1.03 \mathrm{M}$ glucose on gastric acid output in a duodenal ulcer patient (a) before and (b) after truncal vagotomy and pyloroplasty. 


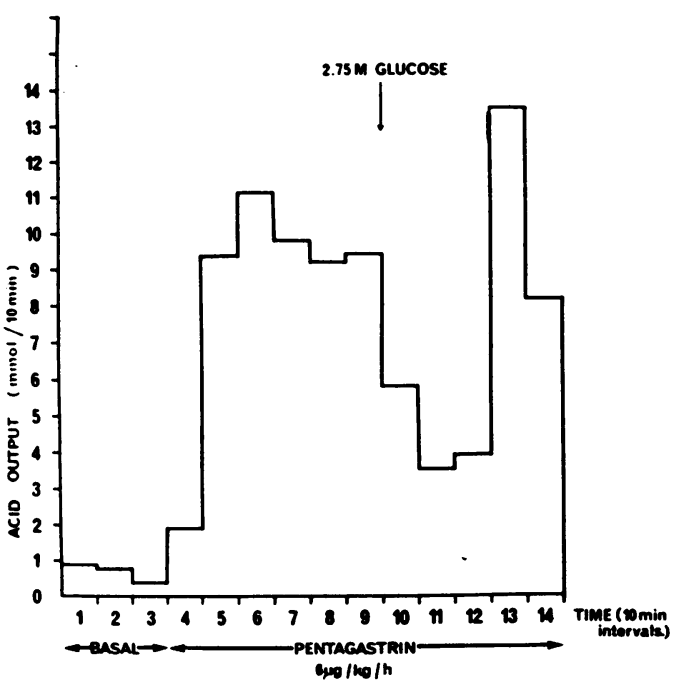

(a)

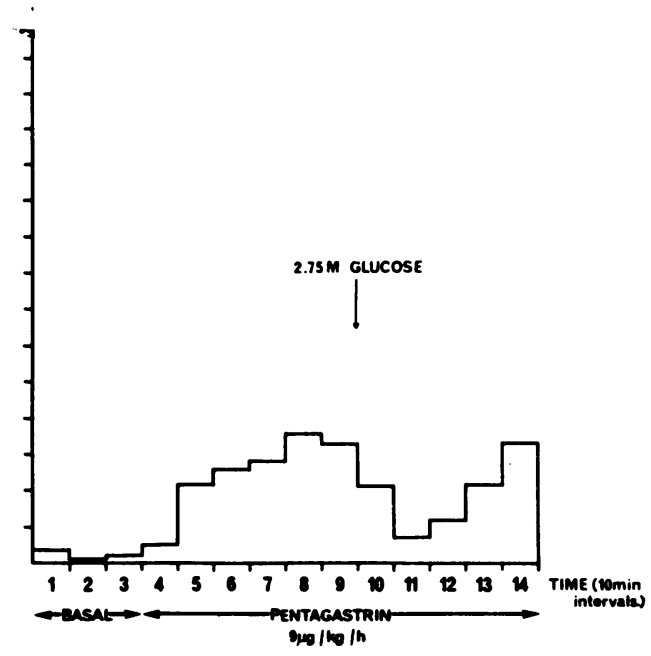

(b)

Fig. 2 The effect of intraduodenal 2.75 M glucose on gastric acid output in a duodenal ulcer patient (a) before and (b) after truncal vagotomy and pyloroplasty.

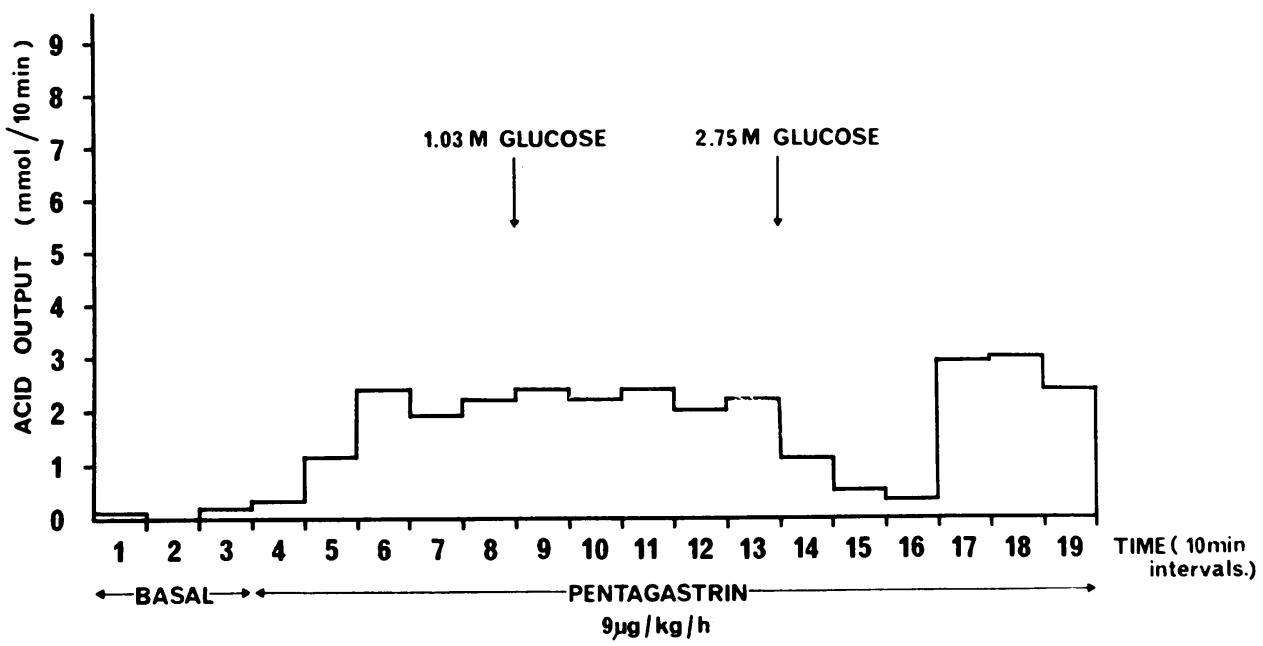

Fig. 3 Comparison of the response to intraduodenal 1.03 M and 2.75 M glucose in a patient after truncal vagotomy and pyloroplasty.

tion in man. The extent to which this type of gastric inhibitory mechanism operates under physiological conditions is uncertain. The concentrations of glucose and saline used in the present study may not be encountered in the duodenum under normal conditions. Nevertheless, the magnitude of the response to these agents suggests that less severe osmotic stimulation may still exert an influence on acid output, particularly at lower rates of gastric secretion.
It has been suggested (Shay et al., 1942a) that the inhibitory response to duodenal acid and other agents may be deficient in duodenal ulcer patients compared with normal subjects and that this deficiency could contribute to the gastric hypersecretion found in many ulcer patients. However, there was no evidence of impaired inhibition among the duodenal ulcer patients in the present study. Other recent workers have similarly failed to detect an impaired 


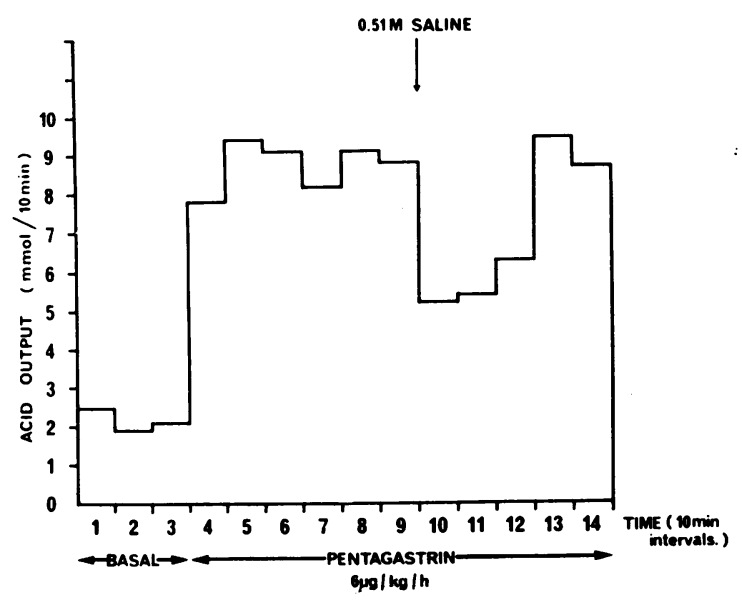

(a)

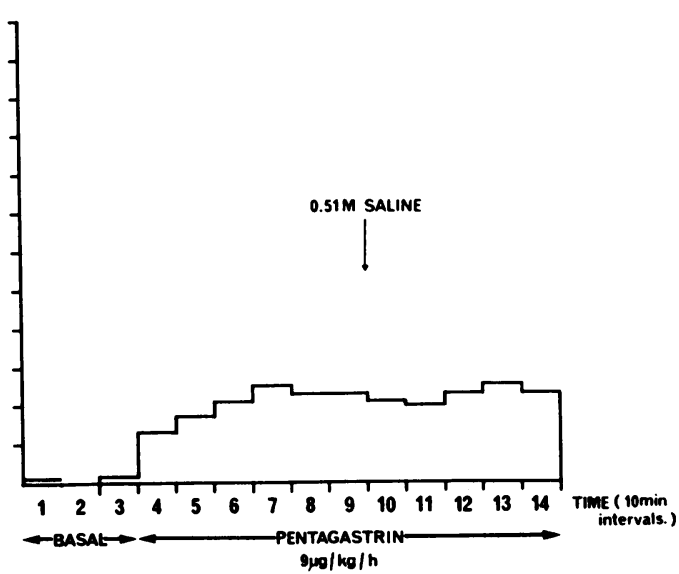

(b)

Fig. 4 The effect of intraduodenal 0.15 M saline on gastric acid output in a duodenal ulcer patient (a) before and (b) after truncal vagotomy and pyloroplasty.

response after intraduodenal acid (Bocheneck et al., 1971) and fat (Windsor et al., 1969).

Although hypertonic saline and $1.03 \mathrm{M}$ glucose produced some inhibition in normal subjects and preoperative duodenal ulcer patients, there was no inhibition following either agent after vagotomy. Failure to respond to duodenal infusion was a uniform finding in the vagotomized patients and it seems likely that the inhibitory effects of hypertonic saline and glucose depend, at least in part, on a vagal reflex in man. A similar claim has recently been made regarding the response to duodenal acid (Ward, 1974). The precise way in which the vagus exerts an influence on the response is uncertain. A direct vagovagal reflex may be involved, though a neurohumoral pathway is also a possibility. This latter mechanism might include either vagal facilitation of hormone release or vagal sensitization of the parietal cells to subsequent humoral action. In the present study inhibition was demonstrable against a secretory background provided by intravenous pentagastrin so that, whatever the nature of the underlying inhibitory pathway, the ultimate action would appear to take place at parietal cell level.

The present results are in contrast with those of Sircus (1958) who was able to demonstrate an inhibitory response to intraduodenal glucose and saline in dogs with totally denervated gastric pouches. However, the solute loads used by this author were much greater than in the present investigation and it is possible that humoral inhibitory factors assume greater importance with higher glucose and saline concentrations, whereas vagal inhibitory mech- anisms predominate at low solute loads. The present finding of a persistent post-vagotomy response after $2.75 \mathrm{M}$ glucose but not $1.03 \mathrm{M}$ glucose would appear to lend support to such a hypothesis. The nature of a gastric inhibitory factor or factors released by high concentrations of glucose remains speculative. The response to $2.75 \mathrm{M}$ glucose is similar to that observed after intraduodenal fat, both from a quantitative and a qualitative point of view and in both cases inhibition appears to persist after vagal section (Ward, 1973). It seems possible, therefore, that similar humoral factors are involved in both situations, though there is as yet no definite information on this point.

Professor H. L. Duthie kindly advised in the preparation of the manuscript. The skilled technical assistance of Mrs Patricia Jackson is again gratefully acknowledged.

\section{References}

Bachrach, W. H. (1962). Laboratory criteria for the completeness of vagotomy. American Journal of Digestive Diseases, 7, 1071-1085.

Bank, S., Marks, I. N., and Louw, J. H. (1967). Histamineand insulin-stimulated gastric acid secretion after selective and truncal vagotomy. Gut, 8, 36-41.

Bocheneck, W., Rodgers, J. B., and Balint, J. A. (1971). Inhibition of pentagastrin-stimulated gastric secretion by duodenal acidification or administration of fat in normal subjects and in patients with duodenal ulcer. American Journal of Digestive Diseases, 16, 865-872.

Hollander, F. (1948). Laboratory procedures in the study of vagotomy (with particular reference to the insulin test). Gastroenterology, 11, 419-425. 
Matsuyama, M. (1932). Influence of the introduction of glucose into the intestine upon secretion of gastric juice. Japanese Journal of Gastroenterology, 4, 273-279.

Ross, B., and Kay, A. W. (1964). The insulin test after vagotomy. Gastroenterology, 46, 379-386.

Shay, H., Gershon-Cohen, J., and Fels, S. S. (1942a). A selfregulatory duodenal mechanism for gastric acid control and an explanation for pathologic gastric physiology in uncomplicated duodenal ulcer. American Journal of Digestive Diseases, 9, 124-128.

Shay, H., Gershon-Cohen, J., Fels, S. S., and Siplet, H. (1942b). Concerning the influence of glucose on the response of the human stomach to test meals. American Journal of Digestive Diseases, 9, 363-367.

Sircus, W. (1958). Studies on the mechanisms in the duodenum inhibiting gastric secretion. Quarterly Journal of Experimental Physiology, 43, 114-133.
Waddell, W. R. (1957). The acid secretory response to histamine and insulin hypoglycemia after various operations on the stomach. Surgery, 42, 652-658.

Ward, A. S. (1973). The effect of vagotomy on the inhibition of gastric secretion by intraduodenal fat. British Journal of Surgery, 60, 533-536.

Ward, A. S. (1974). The effect of vagotomy on the inhibition of gastric secretion by intraduodenal acid. British Journal of Surgery, 61, 698-704.

Ward, A. S., Wilkins, R. A., Cockel, R., and Windsor, C. W. O. (1969). Duodenal inhibition of gastric secretion by osmotic agents in normal subjects and patients with duodenal ulcer. Gut, 10, 1020-1028.

Windsor, C. W. O., Cockel, R., and Lee, M. J. R. (1969). Inhibition of gastric secretion in man by intestinal fat infusion. Gut, 10, 135-149. 